\title{
Ecoteologia e tecnocracia: a ressignificação do kérigma cristão à luz do diálogo com Hans Jonas
}

Orientadora: Lúcia Pedrosa de Pádua

Doutorando: Jesus Manuel Antonio Monroy Lopez

Área de Concentração: Teologia Sistemático-Pastoral

Linha de Pesquisa: Religião e Modernidade

Projeto de Pesquisa: A Antropologia Teológica desafiada pela ecologia integral, no contexto de crise socioambiental

A tese que se apresenta com o título "Ecologia e tecnocracia: a ressignificação do kérigma cristão à luz do diálogo com Hans Jonas" é, sobretudo, um trabalho de teologia pastoral que se inspirou na Encíclica Laudato Si' do Papa Francisco, que lança uma grave preocupação cósmica e humana. Humana-cósmica porque coloca o grave problema ecológico que a humanidade enfrenta diante das catástrofes naturais e talvez diante de um fim do planeta. Pastoral porque se a Igreja prega "novos céus e nova terra", então, fica impossível este anúncio diante do possível fracasso do cosmos destruído pelo sistema econômico, sustentado por uma filosofia que pretende tirar do "depósito" ilimitado da natureza toda sua riqueza. Como pregar um final feliz em que Deus seja "tudo em todos", diante da iminência da catástrofe final? Esta pergunta decisiva foi colocada em outra perspectiva por Hans Jonas, quem procurou oferecer uma resposta ética e teológica a partir da responsabilidade e da teopatia. A obra de Hans Jonas, que, aliás, contesta a gnose, atravessará esta tese para permitir concluir que uma escatologia cristã sem uma responsabilidade que salve o cosmos, assumindo a dor de Deus é impossível, mesmo dentro de uma visão cristã a partir de Cristo morto na cruz e ressuscitado. Essa responsabilidade é um chamado que toca à humanidade toda, a todas as religiões e aos sistemas econômicos. Isso vai permitir um diálogo frutuoso com o pensamento, com as Teologias e especialmente 
com os pobres, principais vítimas do problema ecológico. Esse diálogo deve levar a uma mística que contemple, na alteridade, o problema de maneira antropocósmica. É um novo falar de Deus.

Palavras-chave: Laudato Si'. Hans Jonas. Responsabilidade. Teopatia. Cruz. Pobre. Ecologia. 